Editorial

\title{
Challenges and Results of a Face-to-face Event of Minimally Invasive Colorectal Surgery in a Country which is the World Epicenter of the Pandemic. Lessons Learned
}

\author{
Carlos Ramon Silveira Mendes 1,2,3 (1) \\ 1 Sociedade Brasileira de Coloproctologia, Rio de Janeiro, RJ, Brazil \\ ${ }^{2}$ Serviço de Coloproctologia, Hospital Santa Izabel, Salvador, \\ Bahia, Brazil \\ ${ }^{3}$ Serviço de Coloproctologia do Hospital Geral Roberto Santos, \\ Salvador, Bahia, Brazil
}

J Coloproctol 2021;41(2):109-110.

"Challenges and results of a face-to-face event of minimally invasive colorectal surgery in a country which is the world epicenter of the pandemic. Lessons learned."

Last year has been very different from all that have been lived to date. In March 2020, the new Coronavirus pandemic was declared by the World Health Organization (WHO). Despite the worldwide involvement, each country had its peculiarity and form of presentation.

Regarding teaching, many changes have occurred and difficulties have arisen related to online training, as we were not prepared for this method of learning.

At first, it was strange, we had to quickly adapt to a new reality, but we soon realized that access to information just got easier and faster. At any time or anywhere, it was possible to have a webinar or a live online session on several pathologies and their treatments and even an online congress was held in this very confusing period.

Due to this facility, there was an information "bombardment", with classes and discussions daily, some even taking place at the same time. The months went by and what at first seemed to be wonderful, became tiring.

The information was transmitted with greater practicality, but something was missing...

The Robotic Surgery Experience Bahia was scheduled to take place in person in Salvador, state of Bahia, Brazil, in August 2020. With the advent of the pandemic, we had to postpone it. Then a big question arose: are we still going to try to do a face-to-face event or join the online events modality? It was already September, the desire to hold a face-to-face event was enormous, but the difficulties and uncertainties also grew. Would it be possible? Would it be safe?
The concentration and willingness for online events were no longer the same. We were getting tired...

Considering it, we did not give up and scheduled our event for November. We didn't know what it would be like... Would we have a second wave? Would a face-to-face event still be allowed up to that date?

It was a great challenge, but we missed a face-to-face event, a "contact", even if distant, to meet friends, to exchange experiences... for all that, we kept it the way we planned.

We moved on and sought to know all the rules ... Thus, we had to promote some changes, such as reducing and limiting the number of participants, modifying the location of the event (so that adequate distancing was possible), and making hand sanitizer and masks available. Additionally, we needed to prepare all the necessary structure for a possible online class, in case any speaker could not attend, so as not to lose their participation in the event. After all, everything was done in order to hold the symposium safely.

It took a lot of insistence, persistence and willpower and, finally, the Robotic Surgery Experience Bahia took place.

We had, once again, the opportunity to hold a teaching event on this innovative subject which is robotic surgery. Big names in Brazilian surgery were able to enhance the occasion, which brought more than 20 national guests in 2 days of immersion in robotic surgery.

Throughout the event, caution persisted. The use of masks was mandatory. Before each session, microphones and armchairs were cleaned.

Despite the difficulties of 2020 , it was possible to produce an in-person event taking all precautionary measures. We
Address for correspondence Dr. Ramon Mendes, Avenida Princesa Izabel 855 apto 1901, CEP 40150-550, Salvador-Bahia (e-mail: proctoramon@hotmail.com).
DOI https://doi.org/ 10.1055/s-0041-1730453. ISSN 2237-9363.
(C) 2021. Sociedade Brasileira de Coloproctologia. All rights reserved. This is an open access article published by Thieme under the terms of the Creative Commons Attribution-NonDerivative-NonCommercial-License, permitting copying and reproduction so long as the original work is given appropriate credit. Contents may not be used for commercial purposes, or adapted, remixed, transformed or built upon. (https://creativecommons.org/ licenses/by-nc-nd/4.0/)

Thieme Revinter Publicações Ltda., Rua do Matoso 170, Rio de Janeiro, RJ, CEP 20270-135, Brazil 
were also able to have those moments of chat, exchange of experiences, and a fantastic network with great and new friends.

We hope that more face-to-face events can be held in 2021, strictly following security protocols. We are aware of the difficulties to do it, but we believe in the importance of an in-person meeting, as well as of a webinar.

Conflict of Interests

The author has no conflict of interest to declare. 